\title{
Evaluation of the Optical Properties of Some Coal Types
}

\author{
Asuen G. O. ${ }^{1} \&$ Onyeobi T. U. S. ${ }^{1}$ \\ ${ }^{1}$ Department of Geology, Faculty of Physical Sciences, University of Benin, Benin City, Nigeria Department of \\ Geology, Faculty of Physical Sciences, University of Benin, Benin City, Nigeria \\ Correspondence: Onyeobi T. U. S., Department of Geology, Faculty of Physical Sciences, University of Benin, \\ Benin City, Nigeria
}

Received: June 9, 2013 Accepted: August 12, 2013 Online Published: August 19, 2013

doi:10.5539/jgg.v5n3p176

URL: http://dx.doi.org/10.5539/jgg.v5n3p176

\begin{abstract}
Three sets of Carboniferous coal samples taken from north-eastern England and Scottish Fife were subjected to reflected light oil immersion techniques in an attempt to characterize and differentiate their optical properties.

Although the character of the coals varies remarkably, they are separable into two distinct groups based on rank values. The higher rank values attained by both the South Northumberland and the Howick - fault samples are attributable to thermal influence experienced by these coals due to the Alston block and Whin Sill/dyke respectively. On the other hand, the lower rank values manifested in the Westfield is a reflection of both clean/homogeneous surface and the heavy bitumen staining of the vitrinite particles.

The overall form and type of the maceral groups and their relative distribution in Northumberland and Howick are suggestive of similar deltaic environment of deposition. The Westfield, in contrast, is characterized by the relatively high proportion of alginite macerals believed to be preserved under lacustrine conditions.
\end{abstract}

Keywords: carboniferous coal, optical properties, maceral groups

\section{Introduction}

The optical assessment of a sedimentary material was first established by Hoffman and Jenkner (1932) and today forms the basis for documenting the rank (i.e the degree of coalification), the maceral variation and composition as well as the technical and economic significance of coals. In a strict sense, the optical characterization of any coal reveals the progressive alteration (increasing organic metamorphism) of the macerals. One of the significant indicators for this is vitrinite which is characterized by reflectance, refractive and absorptive indices. The refractive and absorptive indices vary with rank, as the former is a function of atomic density whilst the latter is dependent on the number of delocalized electrons. For example, in a low rank coal, the refractive index assumes the dominant role in determining reflectance value, whereas at higher rank the absorptive index becomes the controlling factor (McCartney \& Hoffer, 1955; Broadbent \& Shaw, 1955; Murchison, 1958).

It is possible also to gain information between the various coals by seeking to know the relative abundance of the natural maceral assemblages (i.e groups). Each of these groups includes a number of macerals having similar genetic and physical properties and mode of preservation.

The objective of this investigation is to determine the rank through vitrinite reflectance and to assess the relative abundance and type of the constituent assemblages of three selected carboniferous coal types. The specimens for this study originated from Northumberland (Westphalian). Howick (Namurian) and from Midland Valley of Scotland (Passage Group) (see Table 1 and Figure 1a). The detailed description and the geologic information of these areas have been discussed in Robson (1980), Brand et al. (1980) and Asuen (1986).

\subsection{Brief Geological Background}

\subsubsection{Northumberland}

The Northumberland coal field consists of coal measures which generalized stratigraphic age is Westphalian (Figure 1a and Table 1). This coal seam occurs in the Lower Coal Measures. The Coal Measures represent a complex history of limited intermittent subsidence over a long period, sometimes punctuated by local spread of coal-forming vegetation across the depositional surface (Smith \& Francis, 1967). One single seam in Northumberland became variously attached with the locality names such as the Beaumont, the Harvey etc with 
no strict geographic distinction other than local nomenclature. The Northumberland coal seam is the most extensively mined seam for commercial purposes in north-eastern England. It is dominantly bituminous in rank.

The samples were recovered from 8 working collieries namely. Weetslade, East Walbottle, North Walbottle, Rising Sun, Bates, Gofton Millpit, Greenside, and Washington F. Table 2 shows the distribution of sampling locations of the coalfield. More importantly, the depositional environment which gave rise to this seam is suggestive of predominantly fresh-water facies, a delta of rather specialized type built up in an area of slow but progressive subsidence which received a copious supply of river drainage (Greensmith, 1971).

\subsubsection{Howick}

The Howick Coal Group is a coal development within the Millstone Grit series. The general process of sedimentation of this coal group comprises also an arrangement of rhythmic sequences commencing at the base with the Great Limestone, the Yoredale type of depositional facies (Robson, 1980; Taylor et al., 1971). Towards the top of the Namurian, several of the phases are either represented as thin coal or absent. During this episode, deltaic and terrestrial environments had a wide influence, while offshore marine conditions were relatively minor (Johnson, 1970) The Howick samples were collected from strata outcropping on the foreshore and cliff sections.

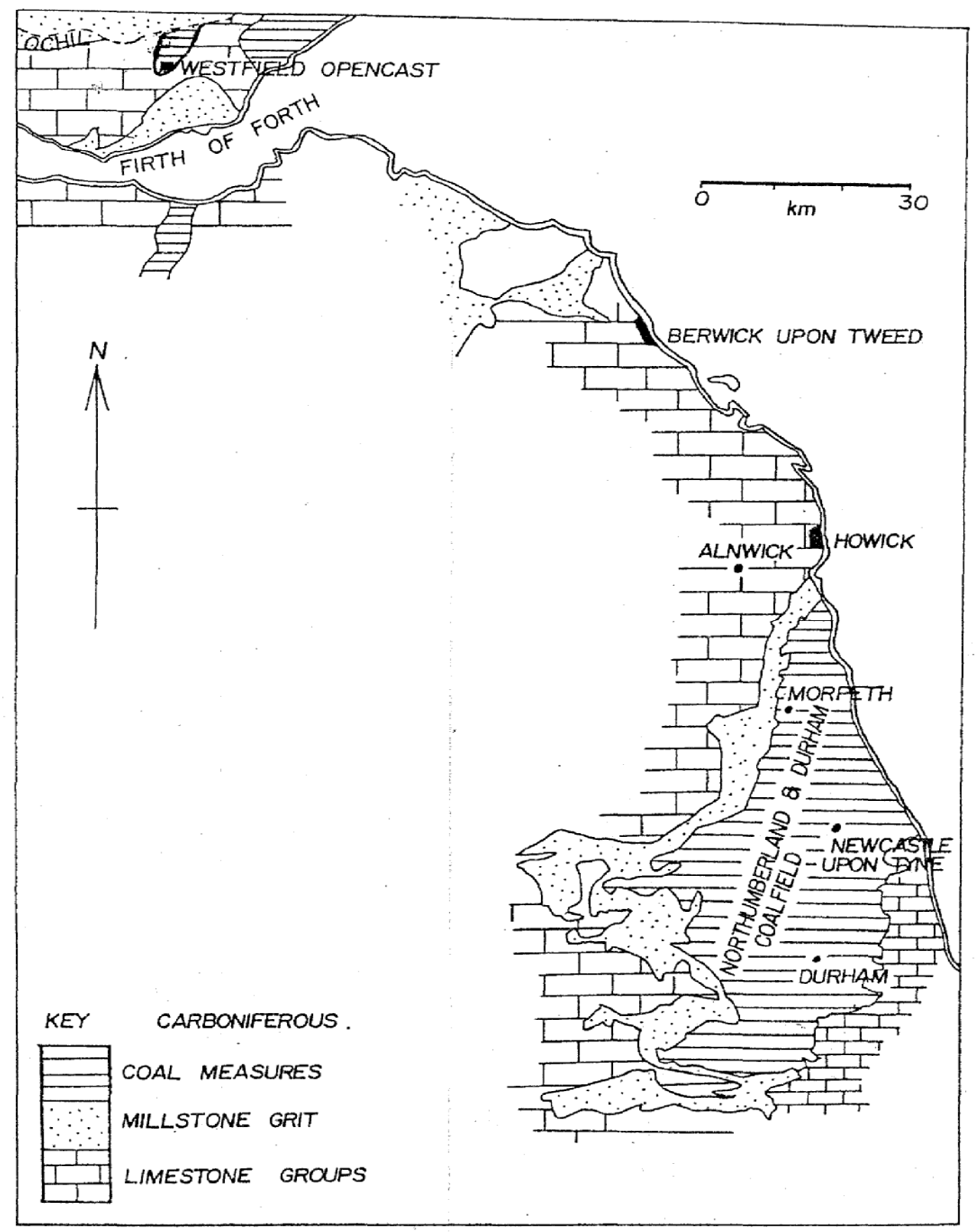

Figure 1a. Generalised sketch map showing the locations of studied samples 


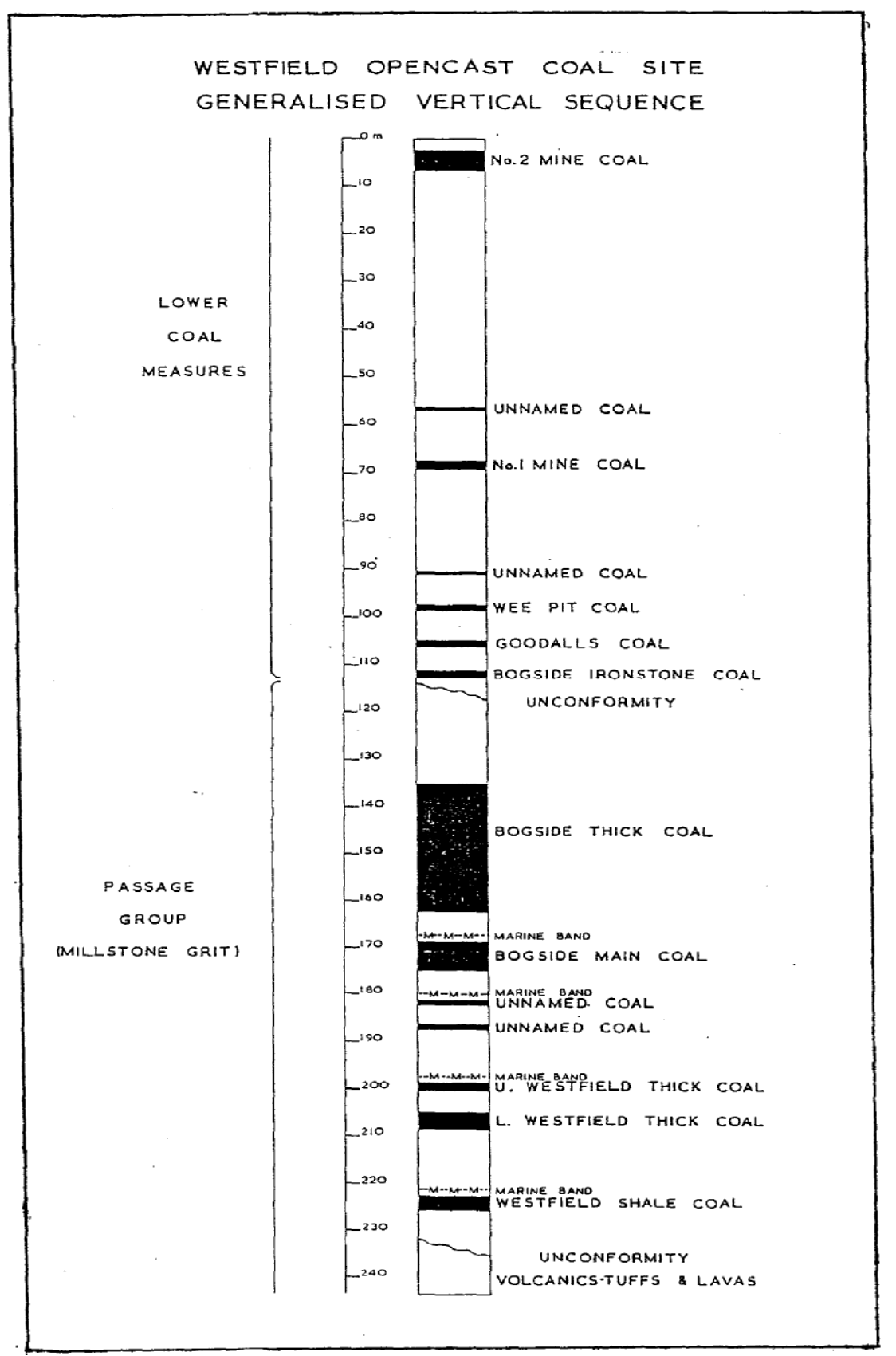

Figure 1b. From N. C. B. Opencast Executive

\subsubsection{Westfield Opencast Coal}

The classification of the carboniferous sequence occupying the Westfield opencast site includes coal, oil shale and iron-stone deposits which, over time, were worked on a small scale. Brand et al. (1980) placed the coals and the related sequence exploited in the area as Namurian.

Although, strictly speaking, the lithology belongs to the Millstone Grit, MacGregor (1960) described it as the Passage Group, because the former appears to be an unsatisfactory name for this locality (see Figure 1b). However, recent evidence has proved the Passage Group to be overlain by thinly bedded coals of the Coal Measures.

Coal sampling here, which centred on the Passage Group (Namurian sequence), were collected from outcrops at the National Coal Board (NCB) open-cast site at Westfield. 
Table 1. Carboniferous coals

\begin{tabular}{|c|c|c|c|}
\hline Stratigraphic Class & Locality & Variety & Remarks \\
\hline Westphalian & $\begin{array}{l}\text { Northumberland } \\
\text { Coalfield }\end{array}$ & $\begin{array}{l}\text { Beaumont } \\
\text { Coals }\end{array}$ & $\begin{array}{l}\text { Formation overlain by shale. A non-marine } \\
\text { influence on a progressively subsiding flood } \\
\text { plain (i.e a river or rivers) }\end{array}$ \\
\hline Namurian & Howick & Parrot Coals & $\begin{array}{l}\text { Formation overlain by limestone (i.e. marine } \\
\text { influence on subsiding coals). }\end{array}$ \\
\hline Namurian & $\begin{array}{l}\text { Westified } \\
\text { Opencast Site }\end{array}$ & Coaly Shale & $\begin{array}{l}\text { Abundant sapropelic organic matter (i.e. } \\
\text { predominantly derived from algae). }\end{array}$ \\
\hline
\end{tabular}

\section{Experimental}

Seventy representative samples crushed to less than $25 \mu \mathrm{m}$ particle size as stipulated in BS 1016 (1957) were made into block specimens. They were then subjected to both grinding on a high-speed rotation lap and on a silicon-carbide paper (grit numbers 220 and 600) and to polishing on successive polishing alumina grades 5/20, $3 / 50$ and gamma. More details of these techniques are available in International Committee for Coal Petrology Handbook (1963). Measuring and determining vitrinite reflectance of the samples were carried out by comparison with a glass standard $\left(\mathrm{R}_{\text {oil }}\right)$ and light conditions at $546 \mathrm{~nm}$ wavelength. The proportion of different maceral groups and mineral matter by volume was also point-counted as defined in the International Committee for Coal Petrology Handbook Classification system. The reflected light optical equipment employed in the investigation consists of a Zeiss standard universal microscope fitted with a stabilized light source, a photomultiplier and a recording system as prescribed by Jones et al. (1968).

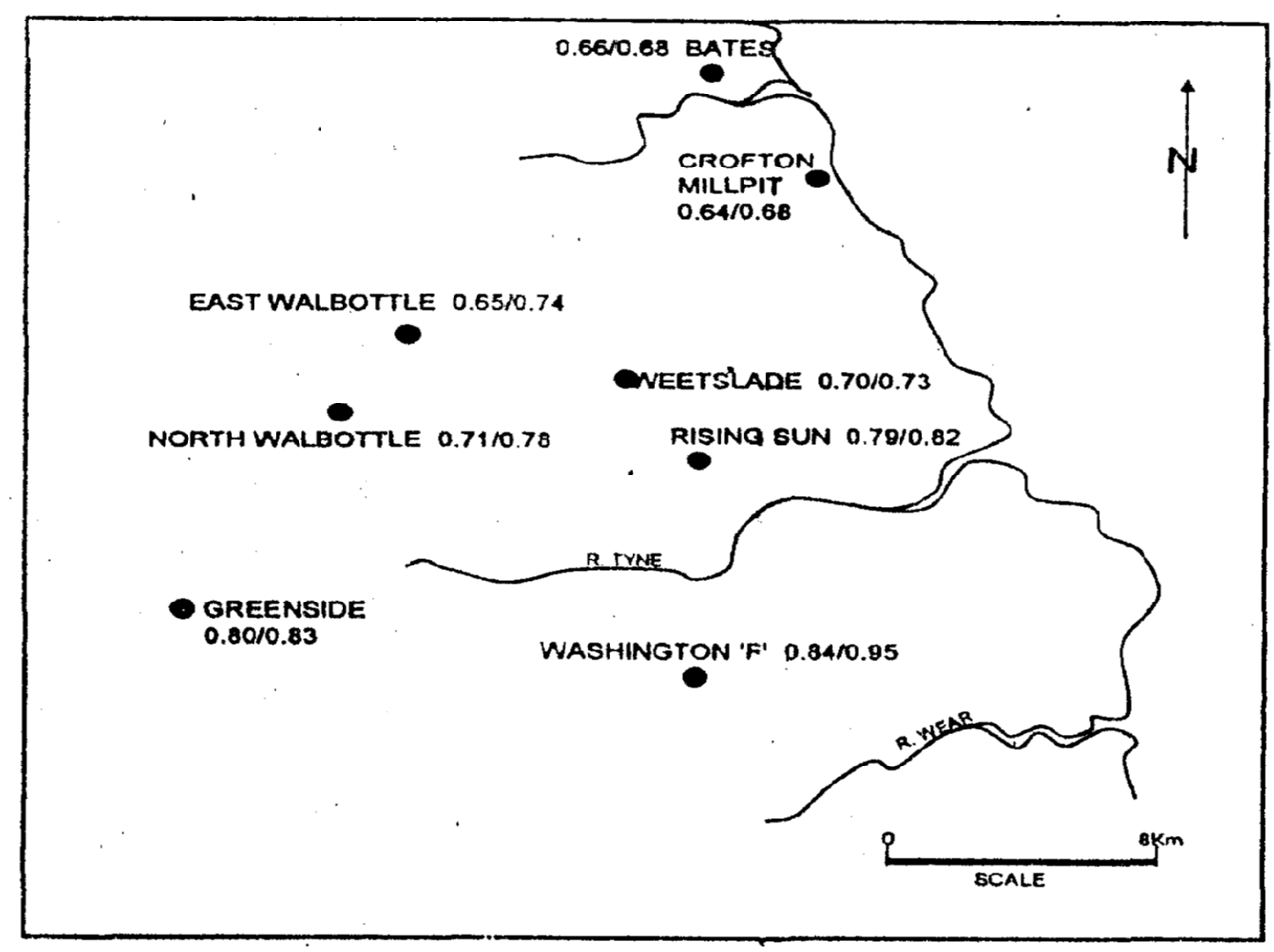

Figure 2. Reflectance (Rm) data for the Northumberland coalfield 


\section{Results and Discussion}

\subsection{Northumberland}

The distribution of the reflectances for this seam over the sampled area represents the lowest and highest values of $R_{m}$ measured from top to bottom of the section (Figure 2). The sampling at various horizons at each colliery within the Northumberland has allowed both vertical and lateral rank variation to be observed. Reflectance $\left(\mathrm{R}_{\mathrm{m}}\right)$ for this group of coals varies between 0.64 and $0.95 \%$. On the basis of reflectance variation, rank increases from roughly north to south. North of the River Tyne, within the Northumberland Trough the coal is generally low in rank but to the South, coal rank tends to be higher, as these coal seams lie on the Alston block where geothermal gradient values have been much higher (Ridd et al., 1970).

In nearly all the samples, vitrinite forms the major part of the maceral composition, ranging from 64 to $76 \%$. In the Greenside bench sample (GR4), vitrinite is as low as $43 \%$, due to the cannelloid character of the coal (Table 2). However, the mean percentage compostions of the fusinite (inertinite) which vary between 14 and $24 \%$ are very mature and show highly reflecting forms. The fusinite, because of its brittle nature, has often been crushed so that the cell walls form angular pieces of fusinite pushed together, giving rise to the so-called 'Bogen-structure'. Within the fusinite and semifusinite cell, voids are frequently filled with mineral matter. The exinite (i.e. sporinite), which never exceeded $13.4 \%$ is well developed. When seen, it frequently shows megaspores with the remnants of their internal cavities represented by a narrow gap between two thick walls which are of medium reflecting character. These bodies are particularly noticeable, as a single spore may extend over a large area. Bell (1966) observed that their occurrences were both as crassispore and tenuispore forms, representing transitional stages between the dull and bright coal lithologies.

Table 2. Mean maceral compositions of Northumberland coals

\begin{tabular}{lcccc}
\hline \multirow{2}{*}{ Colliery } & \multicolumn{4}{c}{ Proportion by volume (percent) } \\
\cline { 2 - 5 } & Vitrinite & Exinite & Inertinite & Mineral Matter \\
\hline Weetslade & 70 & 6 & 19 & 5 \\
E. Walbottle & 72 & 7 & 18 & 3 \\
Greenside & 64 & 8 & 24 & 5 \\
Rising Sun & 76 & 4 & 16 & 4 \\
N. Walbottle & 77 & 6 & 14 & 2 \\
Washington F. & 66 & 7 & 19 & 7 \\
Crofton Millpit & 65 & 10 & 19 & 6 \\
Bates & 66 & 11 & 19 & 8 \\
\hline
\end{tabular}

\subsection{Howick}

These groups of Namurian coals show an increase in vitrinite reflectance to the north. Figure 3 shows the results of the reflectance study on the Howick coal. There is a marked increase in the level of reflectance in the Howick coal approaching the Howick fault from the general level around $\mathrm{R}_{\mathrm{m}}=0.65 \%$ in most of the section of the arrow to $\mathrm{R}_{\mathrm{m}}=1.14 \%$ at the Howick fault (see Figure 3 ). These variations in reflectance suggest that these coals have been locally heat-affected, controlled by the Whin Sill intrusion and an associated dyke at the Howick fault. Coals in the fault zone which exhibited the highest value of $R_{m}$ show brecciation obviously connected with mechanical stress. Coals to the south of the 'arrow' are largely unaffected by the Whin Sill and are part of the "Trough-cold" succession, hence their reflectance values are lower than those in the more northerly part. 


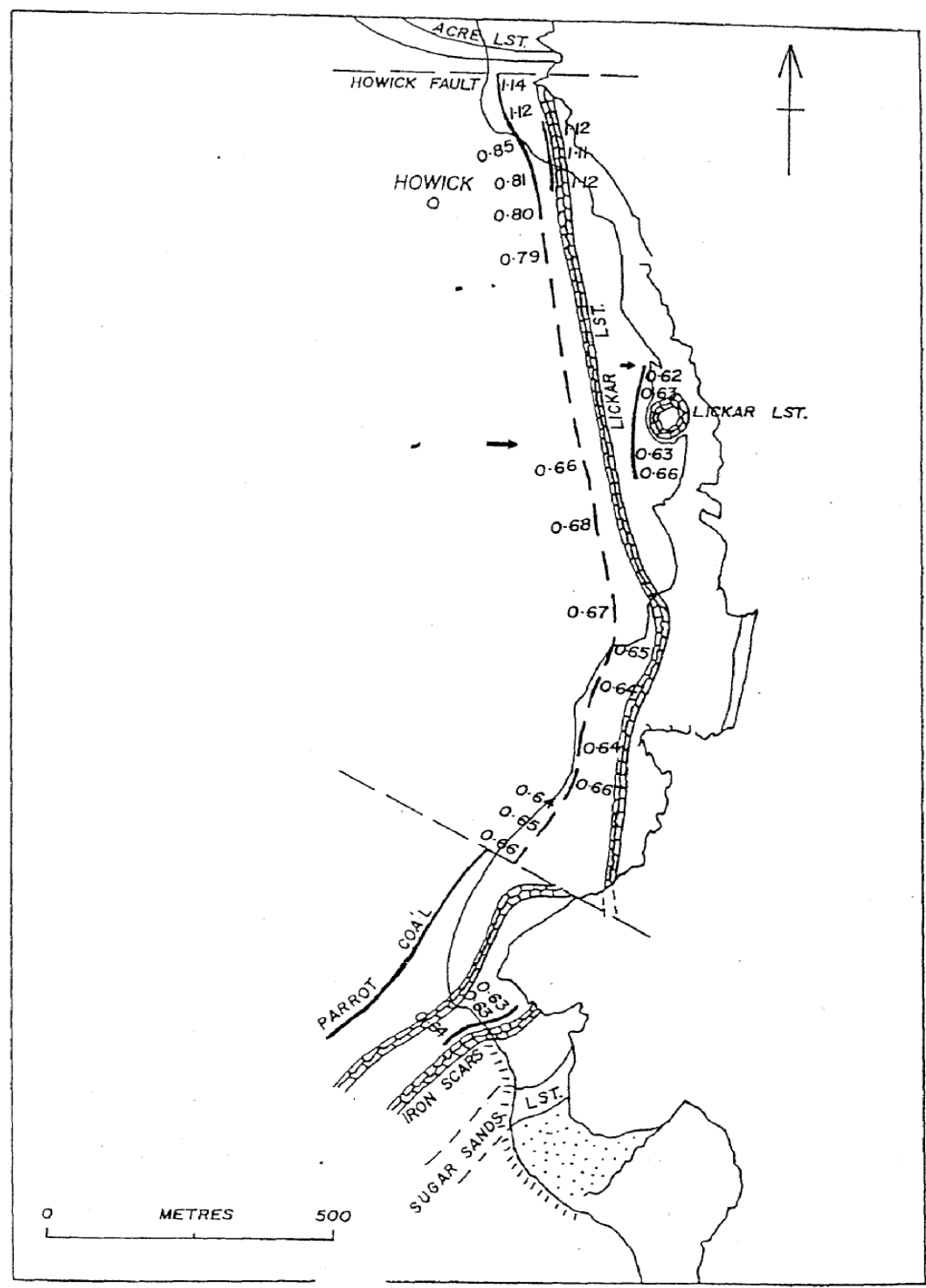

Figure 3. Reflectance (Rm) data for the Parrot and related coals

The mean maceral composition of these coals (shown in Table 3) is very similar to that of the Northumberland coals. The main maceral component is vitrinite, ranging between 57 and $75 \%$, which is usually the structureless collinite type. The inertinite concentration ranges from 15 to 35 percent and may be fragmented or fairly whole, displaying good structure, with semifusinite and fusinite being dominant.

The exinite content is low ranging from 2 to $5 \%$ and is mainly of sporinite. The extent to which this coal has been altered by heat from the Whin Sill close to the Howick Fault is revealed by the loss of the brownish colouration of the sporinites. The brownish colour of the remaining exinite macerals within the coal has not survived the process of rank elevation.

Table 3. Mean maceral composition for Howick coals

\begin{tabular}{lcccc}
\hline Sample & \multicolumn{4}{c}{ Proportion by volume (percent) } \\
\cline { 2 - 5 } & Vitrinite & Exinite & Inertinite & Mineral Matter \\
\hline HW1-HW3 & 60 & 5 & 30 & 5 \\
HW4-HW23 & 63 & 4 & 26 & 7 \\
HWX1-HWX3 & 75 & 2 & 15 & 8 \\
\hline
\end{tabular}




\subsection{Westfield Coaly Shale}

Reflectances for the Westfield 'coaly shale' are shown in Table 4, with a range of values from $R_{m}=0.32$ to $0.39 \%$. In most of the samples one or two groupings of reflectances are also evident. Generally, most values fall between approximately $\mathrm{R}_{\mathrm{m}}=0.37 \%$ and $0.39 \%$; this range may reflect true rank since the reflectance values were obtained from clean and homogeneous vitrinite. Reflectance values as low as $R_{m}=0.32 \%$ may be due to the heavy bitumen staining of the vitrinite. The lowering of the reflectance may also be due to the development of a 'mottled' appearance, reducing the availability of suitable areas for measurement and/or an inferior surface finish on some of the particles. Vitrinite reflectance can also be significantly lowered in the presence of substantial alginite concentrations, probably due to physico-chemical interaction during diagenesis or coalification (Hutton \& Cook, 1980).

Table 4. Vitrinite reflectance $\left(\mathrm{R}_{\mathrm{m}}\right)$ data for Westfield

\begin{tabular}{ll}
\hline Sample Number & $\%$ \\
\hline WF 1 & 0.38 \\
WF 5 & 0.37 \\
WF 8 & 0.35 \\
WF 10 & 0.37 \\
WF 13 & 0.38 \\
WF 15 & 0.39 \\
WF 17 & 0.35 \\
WF 18 & 0.38 \\
WF 23 & 0.37 \\
WF 27 & 0.32 \\
\hline
\end{tabular}

The maceral proportions for this group (Table 5) show a predominance of exinite, which is confirmed under ultra-violet (UV) light. There is a remarkable contrast between the maceral composition of this Coaly Shale and that of the Shaly Coal facies of the Cretaceous Coal Measures of the middle Benue trough of Nigeria, which is mineral matter-dominated with variable amounts of vitrinite and inertinite (Obaje et al., 1998). The technique of UV microscopy allows components, such as clays and alginite, which are otherwise similar in reflected light to be easily differentiated. Alginite shows as distinct clusters and/or unicellular highly fluorescent bodies showing a bright yellow to orange colour. The alginite which thrived particularly well under strongly anerobic conditions and poor aeration was found to range from $59-75 \%$ by volume algal matter. In contrast to other coal types, the organic matter has been subjected to saponification hence the well preserved and persistent algae, a condition suggestive of a sapropel (Stach, 1982). The vitrinite is generally present as dispersed wisps (i.e in the form of stringers) and sometimes as banded vitrinite, frequently associated with varying degrees of staining. The general colour of the vitrinite is unexpectedly dark grey, which may have been connected with the heavy staining. This explains the anomalously low value of vitrinite reflectance on some of the particles. The frequency of occurrence of vitrinite is extremely low, ranging between 8 and $19 \%$ by volume.

\subsection{Comparison of Maceral Contents}

The above maceral proportions in the coals allow some comparisons to be drawn. The values for the different maceral groups: vitrinite, exinite and inertinite + mineral have been calculated and the results of the analyses plotted on a triangular diagram (Figure 4a).

Table 5. Mean maceral composition of Westfield Coaly Shale

\begin{tabular}{lcccc}
\hline Sample & \multicolumn{4}{c}{ Proportion by volume (percent) } \\
\cline { 2 - 5 } & Vitrinite & Exinite & Inertinite & Mineral Matter \\
\hline WF 1-WF 27 & 11 & 66 & 9 & 14 \\
\hline
\end{tabular}




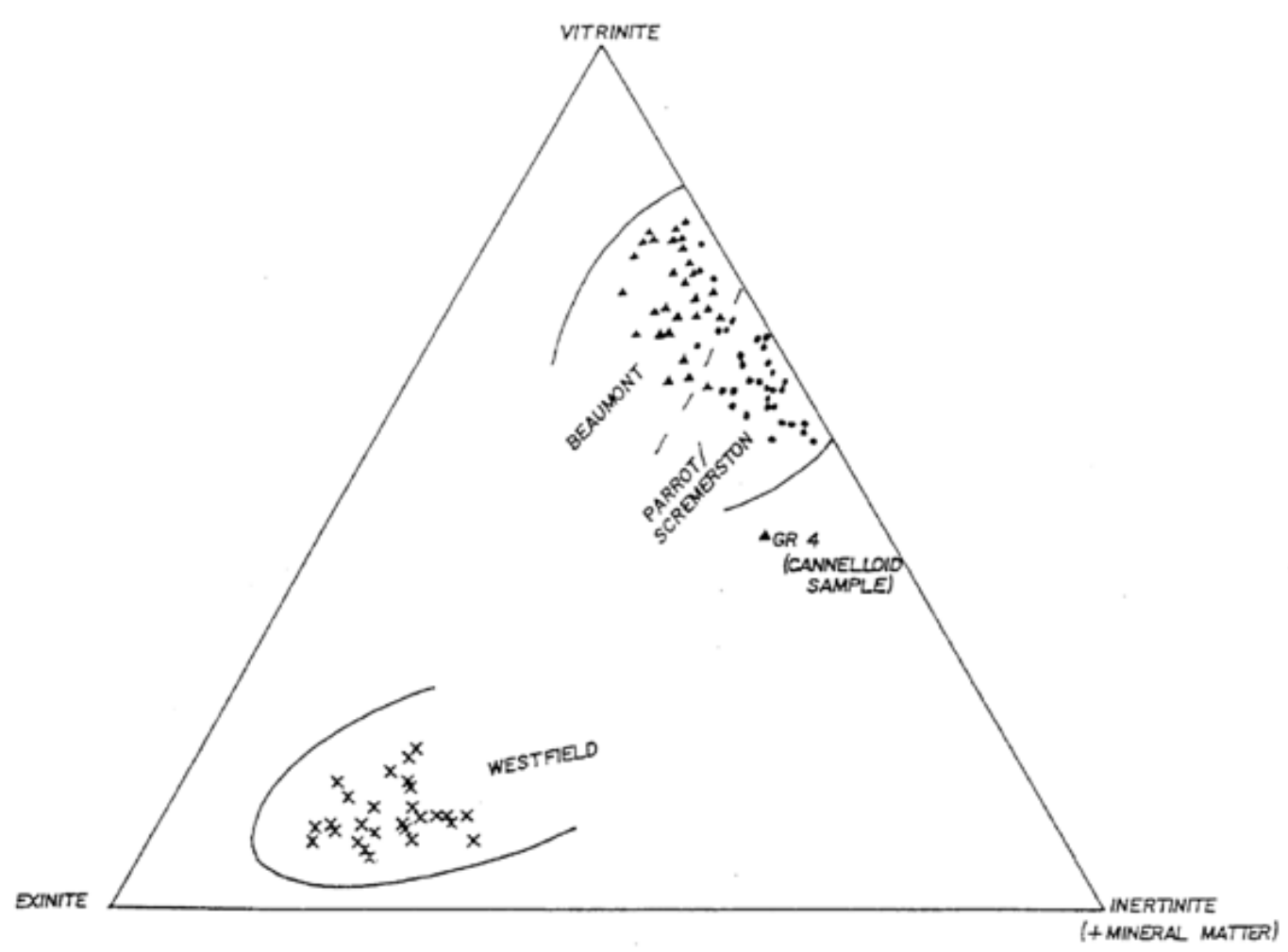

Figure 4a. Maceral composition of studied coals

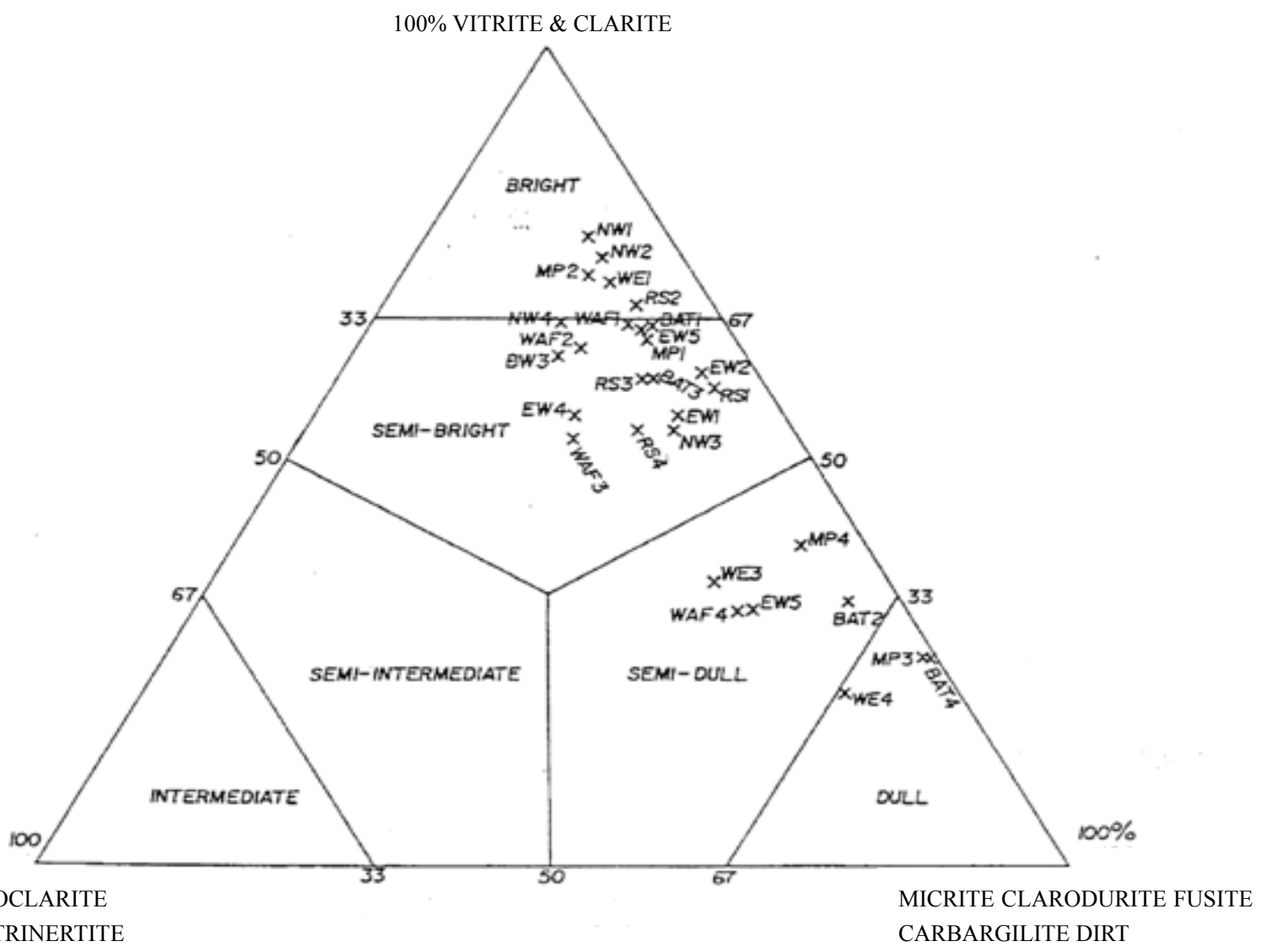

DUROCLARITE

CARBARGILITE DIRT

Figure $4 \mathrm{~b}$. Microlithotype composition of Beaumont coals. Note the use in the classification of varieties of banded coal modified after Hacquebard et al. (1967) 
The principal variation in the plotted results lies between vitrinite and inertinite + mineral matter with all the plots lying almost along the same exinite axis for the Northumberland and the Howick coals. The coal types which are closer to the vitrinite apex are high in vitrinite. Those farther away are richer in inertinite components. This petrographic variation gives both sets of coals a reasonable degree of separation but with a limited area of overlap on the triangular diagram. In general terms, both coals show plots relatively close together because of the transition between the dull and bright lithotypes (Bell, 1966) common to them. The petrographic assessments of the Northumberland and Howick horizons could represent admixtures of one or two lithotypes of banded humic coals, with a sizeable number of Howick samples showing a lower vitrinite content. The Northumberland coals, although showing two lithotype characteristics, dull and bright [BS 1016, 957], still have a vitrinite content higher than other coal samples studied.

The Westfield samples lie close to the exinite apex, mainly along the 10 percent vitrinite line. These samples are generally higher in exinite (i.e alginite) content than the other two coal sets. The Westfield samples are based on the abundance and preservation of algae occurring in clusters and a low content vitrinite and inertinite.

The percentage mineral matter determined under the microscope and which is plotted also in Figure 4a is mainly associated with those infilling inertinite lumens, as well as those occurring in discrete forms. In the light of the inherent difficulties of assessing mineral matter which is finely dispersed, determination of the true mineral-matter content of the coals studied is impossible. The difference between values of petrographically determined mineral-matter and the 'true' value is a function of the degree of dispersion of the mineral matter in the coal.

\section{Conclusions}

The following conclusions can be drawn about the coals.

(1) The dominant occurrence of vitrinite in the Northumberland and Howick coals suggests an availability of cellulose/lignin tissues in the environment of deposition.

(2) Although the Howick maceral groups observed were similar to those of the Northumberland, there is a lower proportion of vitrinite and exinite in these coals. It is believed that the character of this coal may indicate periods of inundation of the peat surface due to local flooding and/or a maintained high water table.

The Westfield samples contrasted with the other coals in their low content of inhomogeneous vitrinite with bitumen staining and abundant exinite (especially alginite) content. An important feature of the high concentration of alginite is believed to be good preservation of organic matter under lacustrine conditions.

(4) The reflectance of Westfield coaly-shale appeared to be sensitive, not only to bituminite staining, but also to the amount of the alginite present. It is thought that the true rank lies between approximately $0.37 \% \mathrm{R}_{\mathrm{m}}$ and $0.39 \% \mathrm{R}_{\mathrm{m}}$ values yielded from clean and homogeneous vitrinite surfaces.

The contrasting vitrinite reflectance value pattern in the North-South areas within Northumberland Trough and Howick results from its function of the differing geological factors (i.e character of the underlying strata and fault zones respectively). It is thought therefore that the true vitrinite reflectance results are restricted to areas unaffected by extraneous influence.

\section{Acknowledgement}

The authors wish to thank Professor D. G. Murchison and Dr. J. M. Jones for their critical comments. Special appreciation is due to the entire staff and students of Organic Geochemistry Unit, University of Newcastle upon Tyne, U.K. for their excellent contribution and assistance.

\section{References}

Asuen, G. O. (1986). Mineralogical Characteristics of two coal types from different Paleoenvironments, Nig. Jour. Min Geol, 23.

Bell, J. A. (1966). The Petrographic character and sedimentary environment of the Harvey-Beaumont seam of Northumberland and Durham (p. 320). (Ph.D. thesis. University of Newcastle upon Tyne).

Brand, P. J., Armstrong, M., \& Wilson, R. B. (1980). The Carboniferous Strata at the Westfield Opencast Site, Fife, Scotland. Rept. Inst. Geol. Sci. Nr. 79/11.

British Standards Institutions. (1957). BS 1016 Methods for the analysis and testing of coal and coke. Proximate analysis of coal-Part 3 . 
Broadbent, S. R., \& Shaw, A. J. (1955). Reflectance of coal Fuel London, 34(4), 385.

Greensmith, J. T. (1972). Petrology of the sedimentary rocks (5th ed., p. 502). Vol. 2. Thomas Murby and Co.

Hacquebard, P. A., Birmingham, T. F., \& Donaldson, J. A. (1967). Petrography of Canadian coals in relation to environment of deposition (p. 84). Symposium of the Science and Technology of Coal. Dept. Energy Mines and resources, Ottawa.

Hoffman. E., \& Jenkner, A. (1932). Die Inkohlung und ihre Erkennung im Mikrobildung, Gluckauf, 68, 81.

Hutton, A. C., \& Cook, A. C. (1980). Influence of alginite on the reflectance of vitrinite from Joadja, N. S. W. and some other coals and oil shales containing alginite. Fuel, 59, 711. http://dx.doi.org/10.1016/0016-2361(80)90025-3

International Committee for Coal Petrology. (1963). International Handbook of Coal Petrography, $2^{\text {nd }}$ Edition and Supplement. Centre National de La Recherche Scientifique, Paris (1963, 1971/72).

Johnson, G. A. L. (1970). Geology of Durham County. Trans. Nat. Hist. Soc. of Northumberland, 41, 1.

Jones, J. M., Murchison, D. G., Scott, E., \& Pickles, S. (1968). Apparatus for reflectivity measurement of reactive and radioactive material. Jour. Royal Micr. Soc., $88,503$. http://dx.doi.org/10.1111/j.1365-2818.1968.tb00631.x

MacGregor, A. G. (1960). Divisions of the Carboniferous on Geological Survey Scottish maps. Bull. Geol. Surv. G.B., Nr., 16, 127.

McCartney, J. T., \& Hoffer, L. T. (1955). E:- Microreflectivity analysis of coal. Analyt Chem., 27, 1320. http://dx.doi.org/10.1021/ac60104a033

Murchison, D. G. (1958). Reflectance of Vitrinite Brennst Chemie., 39, Special Issue, $2^{\text {nd }}$ Int. Conf. Coal Sci., S47.

Obaje, N. G., Funtua, L. I., Liguois, B., \& Abaa, S. I. (1998). Organic Maturation and Coal-Derived Hydrocarbon Potentials of Cretaceous Coal Measures in the Middle Benue Trough of Nigeria.

Ridd. M. F., Walker, D. B., \& Jones, J. M. (1970). A deep borehole at Harton on the margin of the Northumberland trough. Proc. Yorks. Geol. Soc., 38, 75. http://dx.doi.org/10.1144/pygs.38.1.75

Robson, D. A. (1980). The Geology of north-east England (p. 113). Nat. Hist. Soc. Northumberland, Special Publi.

Smith, D. B., \& Francis, E. A. (1967). Geology of the County between Durham and West Hartlepool (p. 354). Mem. Geol. Surv. G.B., H.M.S.O.

Stach. E. (1982). Stach's Textbook of Coal Petrology (3rd ed., p. 535). Berlin: Gebruder Borntraegar.

Taylor, B. J., Burgess, I. C., Land, D. H., Mills, D. A. C., Smith, D. B., \& Warren, P. T. (1971). British Regional Geology: Northern England (4th ed.). London: H.M.S.O.

\section{Copyrights}

Copyright for this article is retained by the author(s), with first publication rights granted to the journal.

This is an open-access article distributed under the terms and conditions of the Creative Commons Attribution license (http://creativecommons.org/licenses/by/3.0/). 